\title{
2 Still a red island? Vienna's electoral geography between stability and change
}

\author{
Elisabetta Mocca and Michael Friesenecker
}

\section{Introduction}

The evolution of the policy domains analysed in this book is characterised by the constant presence of the Austrian Social Democratic Party (SPÖ) as the ruling political force in the city council. Moreover, Vienna's social-democratic political monopoly goes even further back in time than the 30 years accounted for in this book. An urban 'red island' floating in 'a black [i.e. conservative] sea' (Öhlinger, 1993, p. 13 in Novy et al., 2009, p. 133), Vienna's municipality has been controlled by the SPÖ since the foundation of the Austrian Republic and its recognition as a federated authority in 1922 - the Nazi period being the only exception. Such a constant feature warrants inclusion in the equation of policy changes that have occurred throughout the three decades considered in this volume.

Although other European capital cities have been governed by social-democratic forces (such as Berlin, Stockholm and particularly Copenhagen), these have not remained in power for almost a century like in Vienna. However, the long-standing social-democratic control of the Austrian capital has not attracted much academic attention, with only a handful of works published, relatively recently, in international scholarly outlets. Research on the topic has analysed Vienna's social-democratic leadership, mainly from an electoral standpoint, focusing on party organisation and the electoral system (Abedi and Siaroff, 1999; Ennser-Jedenastik and Hansen, 2013). To complement these accounts, this chapter explores the relation between Vienna's lasting social-democratic regime and its generous redistributive policy. We rely on redistribution as an element of justice (Fraser et al., 2003; Fainstein, 2011), residing at the core of this book, as the analytical lens through which to interpret the Viennese social-democratic dominance. We maintain that, in order to cast light on the Viennese 
social-democratic regime, it is necessary not only to examine the SPÖ's territorial organisation and the Austrian electoral arrangements, as previous research has done, but also to factor in the municipal welfare system of social-democratic mould. Vienna's welfare system is characterised by its generous provision across a broad spectrum of services (including social housing, employment policy, utilities, public transport, education and leisure activities; Hatz et al., 2015). By couching the analysis of the policy outputs in the ideological foundations of Vienna's model, this chapter brings policy into conversation with politics.

This approach is operationalised through a multi-phase analysis. First, we map the Austrian parties' national electoral performances to verify whether the red island trope still applies (Section "The national elections: a red island in a darkening sea"). Second, we focus on Vienna's electoral landscape by comparing different patterns in national and municipal elections at a sub-municipal level (Section "An increasingly colourful landscape: national and municipal elections in Vienna"). Third, in line with previous research identifying a link between spatial patterns of quality of life and electoral outcomes at national (see Hagerty et al., 2000) and subnational levels (e.g. Lieske, 1990; Ouweneel and Veenhoven, 2016), we analyse the relation between the spatial patterns of municipal elections' outcomes and the aggregated satisfaction of Vienna's residents in relation to socio-economic and environmental conditions and services at the sub-municipal level (Section "The political strength of Vienna's social-democratic regime"). The findings from the analysis are discussed in the concluding section.

\section{The national elections: a red island in a darkening sea}

The endurance of the municipal social-democratic government harks back to the early decades of the past century. In the 1920s, Vienna started being portrayed as 'a red island' in the conservative 'black sea' of the rest of the country, to describe the social-democratic 'reformist project of redistribution' (Öhlinger, 1993, p. 13 in Novy et al., 2009, p. 133). This phrase, to some extent, still vividly underscores the divergence between the City's electoral patterns and those of the rest of Austria. Throughout the last 30 years, this trend has become even more pronounced (Table 2.1). In comparison to other federal states and state capitals in Austria, the SPÖ has consistently been the party in Vienna obtaining the majority of the votes in the national elections. The increasing popularity of the right-wing populist Austrian Freedom Party (FPÖ), coupled with a larger consensus gained by the conservative 
ÖVP, have shifted the electoral preferences of the other federal states towards the right of the political spectrum since the late 1990s. It has been argued that, at the national level, the Proporz system - which foresaw the distribution of political functions, public bodies and social partners between the SPÖ and ÖVP - combined with the consociational architecture of Austrian politics (leading to a convergence between the two main parties) fuelled anti-establishment feelings, harnessed by the FPÖ from the 1980s onwards (Art, 2007, p. 334).

Vienna, as a federal state and a municipality, constitutes the most faithful of the SPÖ's stronghold, never switching its political allegiance during the period under consideration, and even beyond (Table 2.1). By way of contrast, the capitals of the other federated states display less continuous party support (except for Eisenstadt for the ÖVP and Linz for the SPÖ), swinging from one of the two main parties, with the FPÖ and the Greens making some gains. Looking at the national electoral results at Bundesland level, the national electoral data confirm the image of Vienna as an urban red island amid a sea of Länder whose political preferences at some point swung to (or, always been for) the right of the political spectrum.

Table 2.1 National elections: parties with most votes per federal states and capitals, 1990-2019

\begin{tabular}{|c|c|c|c|c|c|c|c|c|c|}
\hline States/state capitals & 1990 & 1995 & 1999 & 2002 & 2006 & 2008 & 2013 & 2017 & 2019 \\
\hline Burgenland / Eisenstadt & & & & & & & & & \\
\hline Carinthia / Klagenfurt & & & & & & & & & \\
\hline $\begin{array}{l}\text { Lower Austria / Sankt } \\
\text { Pölten }\end{array}$ & & & & & & & & & \\
\hline Upper Austria / Linz & & & & & & & & & \\
\hline Salzburg / Salzburg (City) & & & & & & & & & \\
\hline Styria / Graz & & & & & & & & & \\
\hline Tyrol / Innsbruck & & & & & & & & & \\
\hline Vorarlberg / Bregenz & & & & & & & & & \\
\hline Vienna & & & & & & & & & \\
\hline Austria & & & & & & & & & \\
\hline
\end{tabular}

Austrian Social-Democratic Party (SPÖ)

Freedom Party of Austria (FPÖ), except for 2008: Alliance for the Future of Austria (BZÖ)

Source: Own calculation based on SORA, 2019, National election results Austria 1919-2017 (OA edition), doi: 10.11587/EQUDAL, AUSSDA Dataverse, V1. 


\section{An increasingly colourful landscape: national and municipal elections in Vienna}

We now turn to examine Vienna's national and municipal electoral results, unpacking the parties' performance at the district level. The purpose of this analysis is twofold: first, it investigates whether the SPÖ's hegemony has remained uncontested at national and local elections; second, the focus on the local elections lays the groundwork for the correlation analysis performed next. Since Vienna is both a municipality and a Bundesland, municipal elections are the same as the Länder elections, and function as elections to the city council.

Austria's territorial variations in electoral patterns have been observed by some international electoral research. Abedi and Siaroff (1999) reported on how Länder and national election results showed divergent trends in the 1983-1997 period, identifying the driver of this rift in the ÖVP's localised party structure, which conferred its greater electoral success in the Länder elections. The authors found that the SPÖ's electoral patterns in Vienna did not reflect an increasing divide between Länder and national elections, but rather displayed similar voting performances at both levels (ibid.). On the contrary, EnnserJedenastik and Hansen (2013, p. 787), who study the nationalisation of Austrian party systems, suggest that 'the most nationalised party system is found in Vienna', as cities have always been the socialdemocratic bulwarks in Austria.

Our analysis shows that the synchronous voting pattern reported by Abedi and Siaroff (1999) for Vienna at the city level until the 1990s shifted at beginning of the millennium (Figure 2.1). By breaking the development of the national electoral results down by district level and comparing it to the municipal electoral results, the picture confirms a diverging, but also changing, pattern between national and local elections. In the 1990s, the overwhelming majority of districts voted for the SPÖ in the national elections, with some leaning towards the ÖVP, although the vote shares for the SPÖ decreased over time in almost every district (Figure 2.1). The 2000s witnessed the entrance of the Greens in the national political arena. Since the 2002 national elections, the Greens gained growing consensus in the wealthier inner districts. Such progressive growth was halted in 2017, when the Greens were wiped out from Vienna's electoral map due to a party split at the national level. Voters in the green districts then mostly returned to the SPÖ. However, the Greens made a successful comeback in the 2019 national election, forming a coalition with the ÖVP at the federal level. The Greens' electoral triumph is reflected in the electoral map 
Elections to the National Council

2019

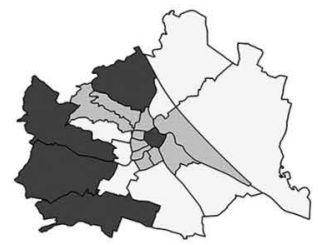

2013

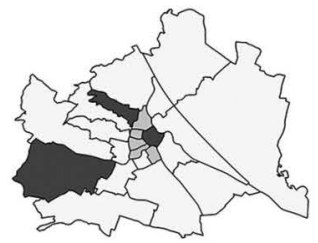

2008

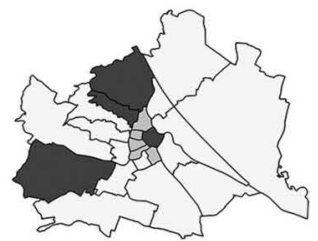

2006

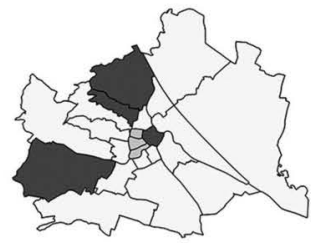

2002

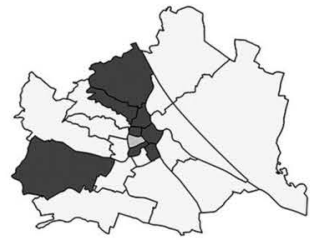

1995

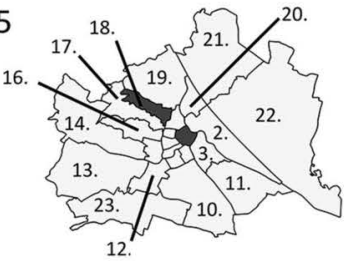

Social Democratic Party (SPÖ)

Freedom Party of Austria (FPÖ)
Elections to the City Council

2020

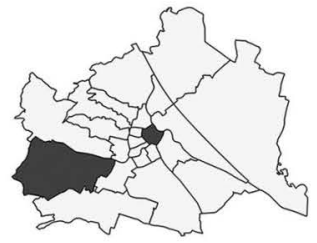

2015

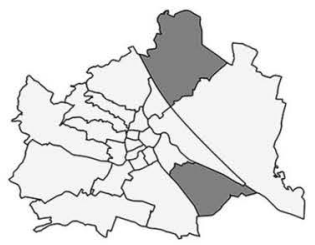

2010

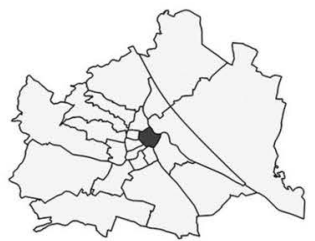

2005

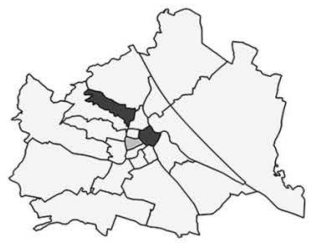

2001

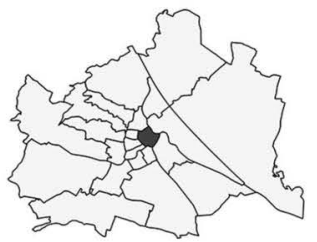

1996

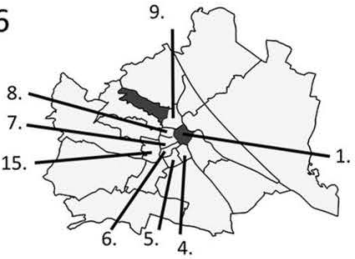

The Green Party

Austrian People's Party (ÖVP)

Figure 2.1 Comparison of national and municipal elections: parties with most votes per districts, 1995-2020.

Source: Data.gv.at CC BY 4.0, Statistical Yearbooks of Vienna, BMI - https://bit. ly/3tOCNTf, Author's own elaboration. 
of Vienna, where the party gained a majority of votes in 10 out of 23 districts, especially in the inner districts. This changing electoral outcome appears to be related to an increasing re-urbanisation of innercity districts by new urban middle classes and a slightly stronger effect of socio-economic features in explaining socio-spatial segregation (Hatz et al., 2015). However, the same election also saw the ÖVP gaining the majority of votes in the outer, wealthier districts and in the first district (an ÖVP bulwark for the time frame considered).

The national elections witnessed a weakening of the red island metaphor in the new millennium. Meanwhile, the data show that this trope has held up for the city council elections, with the SPÖ gaining the overwhelming majority of the districts over the timespan considered. However, other parties, primarily the ÖVP but also the Greens and, more recently, the FPÖ, made limited inroads in the municipal electoral competition.

From 1991 to 2001, the ÖVP constituted the only opponent of the SPÖ in very few districts (Figure 2.1). The first district is strongly conservative, with the ÖVP being the most voted-for party in all of the elections considered in our study - except for the 2015 municipal elections, when the SPÖ took the most votes in this district. In 1996, the change of the Viennese SPÖ's leadership (Michael Häupl replaced Helmut Zilk) led to the party's lowest historic result, forcing it to form a coalition with the ÖVP. In 2001, the SPÖ regained full control of the city council with no coalition partner.

While not gaining the majority of the votes in any Viennese district, the FPÖ fared well in the 1991 municipal elections, when it obtained $22.5 \%$ of the votes, 'more than doubling its total from 1987 and robbing the SPÖ of the absolute majority it had enjoyed since 1954' (Art, 2007, pp. 343-344). More importantly, the 2015 elections saw the FPÖ conquering the 11th and 21st districts - working-class areas with a high density of social housing. This pattern seems to be associated with an increasing residualisation of low-status groups in municipal housing estates (Hatz et al., 2015). In 2015, the FPÖ received nearly one-third of the votes $(30.79 \%)$, their highest share of the votes ever obtained in Vienna. Therefore, since the 1990s, the FPÖ has acquired growing political weight in the city council. However, the national scandal of the FPÖ, the so-called Ibiza affair in 2019 , which also led to a local party split, massively weakened the FPÖ's influence in the 2020 elections. Indeed, FPÖ votes dropped from around 30\% to 7\%, with many voters either returning to the SPÖ or abstaining.

The Greens appeared to be a less challenging opponent for the SPÖ at the municipal level, as their vote shares in the inner-city districts 
are lower than in the national elections. This suggests that potential Greens' voters make a clear distinction between national and local policies. In Vienna's electoral map, the Greens only appeared in 2005 when they gained the majority of votes in the 7th district - which displays higher concentrations of young, well-educated urban professionals and creatives - then quickly disappeared again in the next elections (Figure 2.1). While the Greens' political relevance should not be understated, being the junior partner in two coalitions with the SPÖ from 2010 to 2020, their shares of the votes in municipal elections are, on average, fairly modest when compared to those gained in the national elections.

The data show that Viennese voters tend to vote differently in the national and municipal elections. While not rejecting the validity of previous research considering the voting system and party organisation as factors that favoured the SPÖ's control of Vienna, we analyse the century-long city's allegiance to the SPÖ at the municipal level in relation to local social policies implemented by the latter. In the next section, we probe this relationship.

\section{The political strength of Vienna's social-democratic regime}

The key role of the municipality in service delivery harks back to the second decade of the 19th century. In particular, since 1919, under the leadership of Reumann (the first social-democratic mayor) and especially after becoming a Bundesland in 1922, the city embraced an extensive programme of reform that was of municipal social-democratic bent, entailing municipal control and provision of goods and services, such as housing, welfare, healthcare, education and culture (Graicer, 1989; Kadi and Suitner, 2019). As documented in the other chapters in this volume, the City's policies were adapted to socio-economic and institutional changes, such as population growth, socio-demographic changes and EU membership. While part of the early social-democratic legacy is still entrenched in the City's generous system of public service provision, today's ideological posture in Vienna has moved away from the original municipal socialist stance in favour of a mild neoliberal policy style (Novy and Hammer, 2007). Notably, Vienna's inclusive social housing approach has been impacted by a recommodification of some housing segments, which has compounded the social and spatial divide (Hatz et al., 2015; Kadi, 2015, see Chapter 4 by Litschauer and Friesenecker in this volume). Similarly, in recent decades, social disparity has increasingly affected the Viennese labour market (Chapter 7 by Riederer et al. in this volume). 
To explore the relationship between patterns of satisfaction with socio-economic and environmental conditions, the City's service provision and voting patterns, we undertook a correlation analysis at district level. Additionally, we checked for potential correlations between spatial patterns of voter turnout and satisfaction to shed light on the possible role of protest votes. We employed data drawn from (i) the Viennese Quality of Life Survey (VQLS), and (ii) the city council elections. While the first of these sources accounts for the spatial pattern in the aggregated residents' degree of satisfaction with the City's services, socio-economic conditions and living environment per district, the latter provided area-based data on each of the main parties' electoral performance since $1996 .{ }^{1}$ Due to data constraints, we selected data from the elections that were as close as possible to those of the VQLS (elections: 1996, 2005, 2010, 2015 and 2020; VQLS: 1995, 2003, 2008, 2013 and 2018). The VQLS, with a sample size of around 8,000 respondents, is representative of the populations of the Viennese districts. Unfortunately, as the VQLS does not provide individualised electoral indicators, we combined this database with area-based national and municipal electoral data. In light of the perils of the 'ecological fallacy' lurking in those analyses 'drawing inferences about individual behaviour from aggregate data' (Kramer, 1983, p. 92), we avoid interpreting individual relationships between satisfaction and voting behaviour and focus on relations between spatial patterns of electoral outcomes and satisfaction levels.

The data indicate a significant positive correlation between the composite satisfaction indicator and voter turnout (Table 2.2). This result suggests that areas displaying higher life satisfaction are more likely to vote in the municipal elections, whereas areas characterised by lower satisfaction show less political participation in local elections. To refine our analysis, we run a correlation between satisfaction for different socio-economic and urban aspects and parties' share of the votes.

From 2010 onwards, the results for the SPÖ indicate that those districts where people are, on average, more satisfied show lower probabilities for high SPÖ votes in the city council elections (despite both the SPÖ's vote shares and life quality satisfaction always remaining fairly high). In particular, the analysis of the individual policy domains of the composite indicator suggests that the lower the perceived quality of the neighbourhood and cultural offer in a district, the lower the SPÖ's share of the vote for the entire period tends to be. Since 2010, low levels of satisfaction with the housing situation and, since 2015, the household financial situation have been related to levels of SPÖ votes. Satisfaction with environmental quality and occupational conditions 
recently seems to have become less important in relation to spatial patterns of sub-municipal SPÖ strongholds.

As for the FPÖ, the results show a significant negative correlation between the district's vote share and satisfaction with the neighbourhood and cultural offer. More markedly in the last election, the correlation results appear to be broadly similar to those displayed by the SPÖ: our findings indicate a negative correlation between the FPÖ's share of the votes and levels of satisfaction for a series of indicators, such as household financial conditions, occupation, housing, transport, health system and administration.

Moving to the ÖVP, the data show a statistically significant positive correlation, especially between ÖVP's vote share and the district's levels of satisfaction for the neighbourhood and also cultural offer, although almost no significant correlations could be measured for 2020. Additionally, for some of the years under analysis, there is a positive correlation between the ÖVP's share of the votes and housing situation, environmental quality, household financial situation and occupation. To some extent, the correlation results for the ÖVP's vote share and life satisfaction appear to mirror opposite circumstances to that of the SPÖ. This may point at the different electoral base of the two parties, with the ÖVP more likely to attract well-off voters.

Regarding the Greens, besides a negative correlation between the district's vote shares and lower levels of satisfaction with local kindergartens, the data for the last election point at a positive significant correlation with the composite satisfaction indicator. Indeed, the share of Greens' votes positively correlates with districts that show higher satisfaction with the neighbourhood, public transport, health systems, occupation and the administration. With regard to Neos, a liberal party founded in 2012 (Ennser-Jedenastik and Bodlos, 2019), the highly significant positive correlation of the last two elections relate predominantly to districts with higher levels of satisfaction from many aspects, especially the neighbourhood, the housing situation and the financial position of the household.

To better interpret the correlation results, we examined the relationship between the parties' vote shares and life satisfaction by district. An interesting finding is the correlation results for those districts lying below Vienna's average net-income, such as the 10th, 11th and 20th districts (Stadt Wien, 2020, p. 150). These districts display higher probabilities of voting for the SPÖ (Figure 2.2). These very same areas also appear to have higher vote shares for the FPÖ, hinting at how the latter may erode the electoral base of the Social Democratic Party. It is worth noting that the 20th district has recently become one of the 


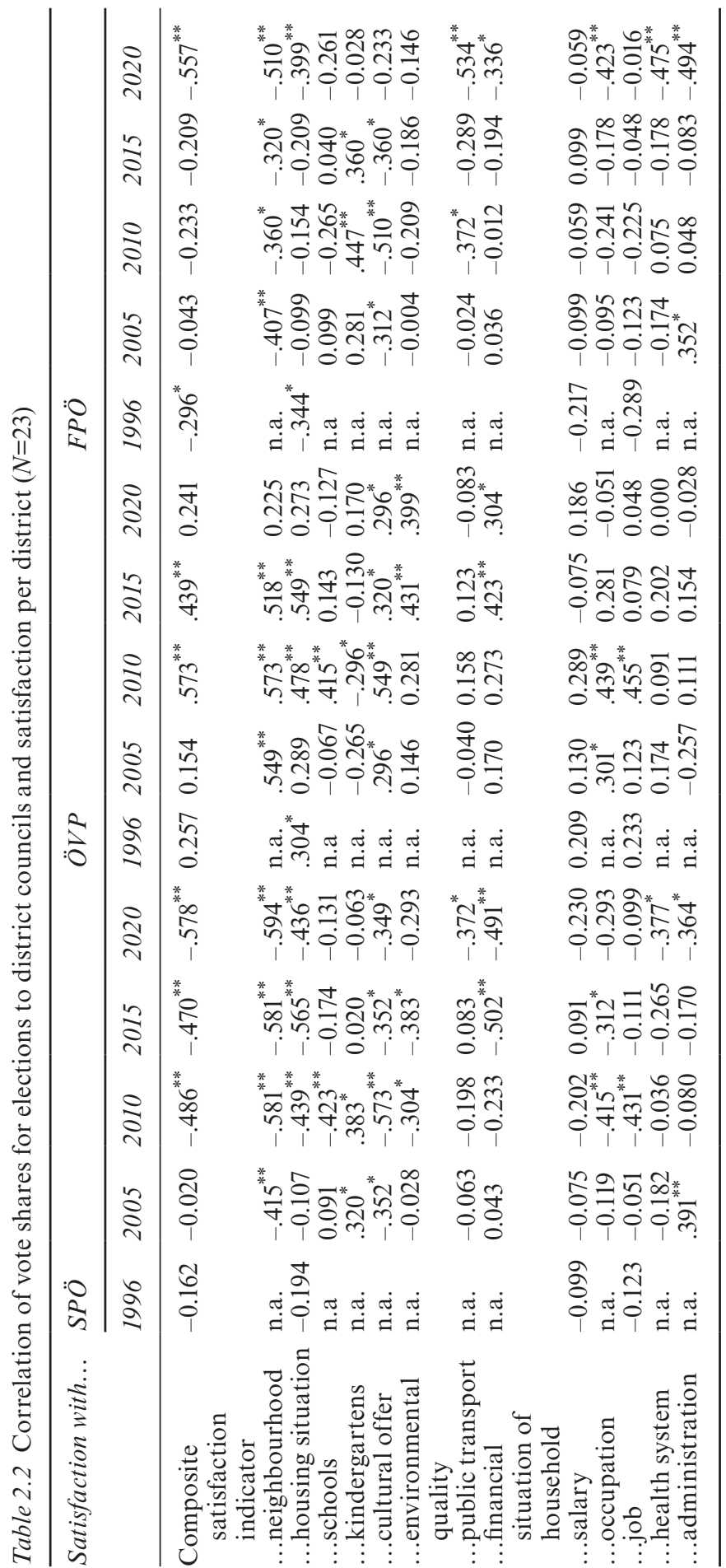




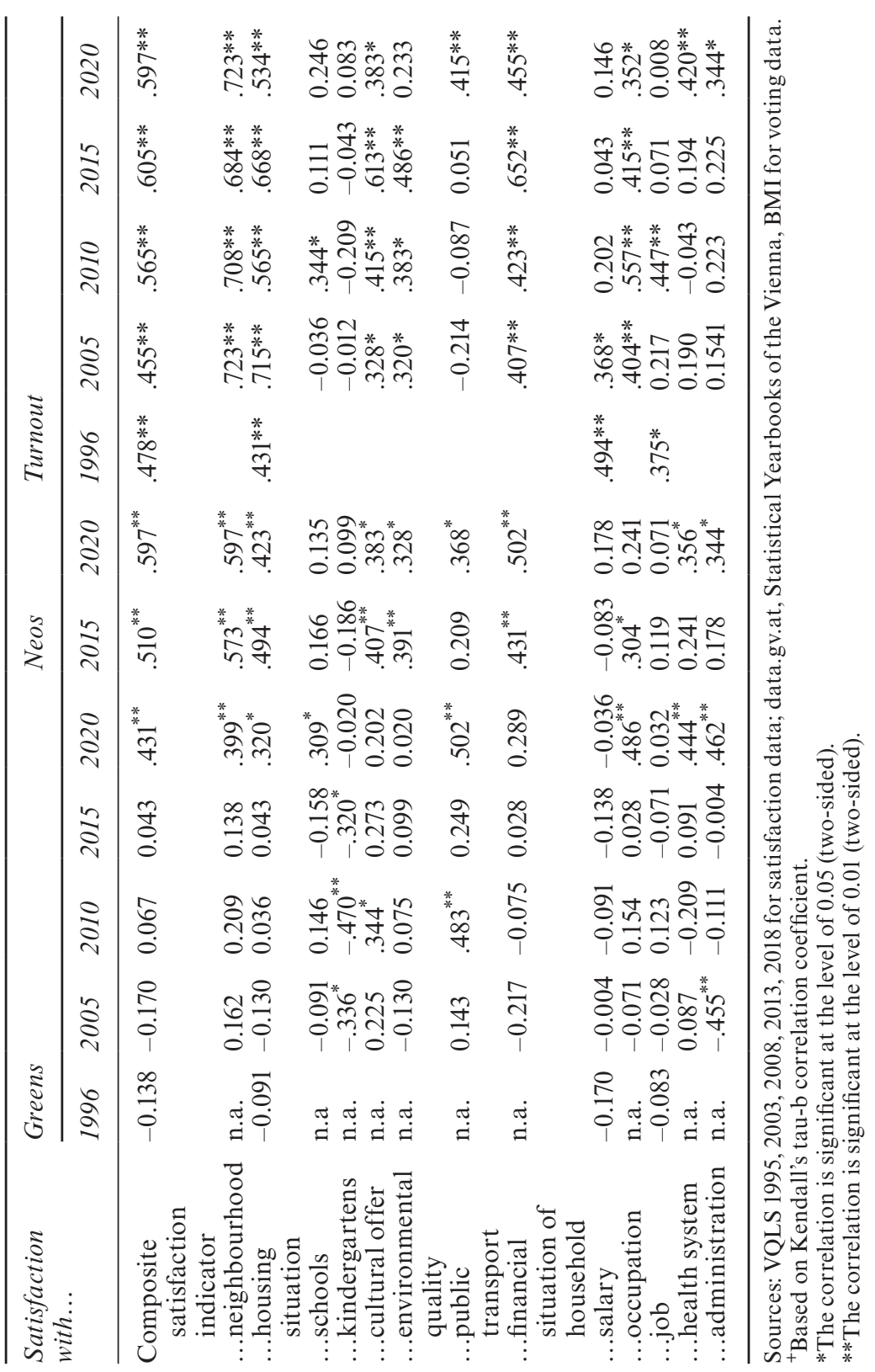


most diverse in Vienna, where slightly over $50 \%$ of residents have a migration background and $23.8 \%$ of the population do not have the right to vote in any elections; similarly, the 10th and 11th districts are comprised of a sizeable portion of non-native residents, among which $23.4 \%$ and $18 \%$, respectively, cannot vote in any elections. ${ }^{2}$ Further, these three districts seem to be less likely to vote for the ÖVP, Greens and Neos. The district-level results appear to confirm the existence of a spatial relationship between high levels of life satisfaction and
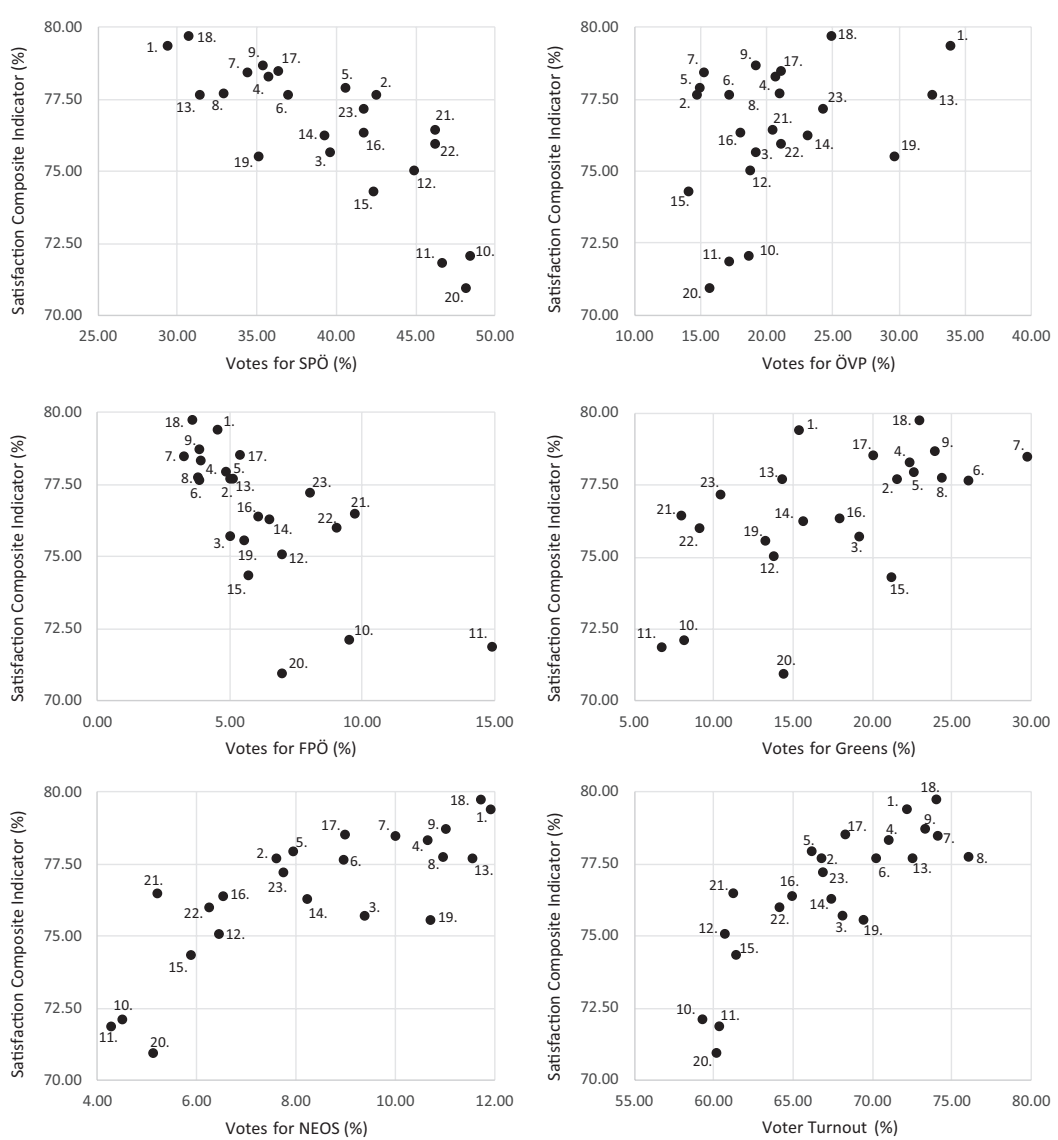

Figure 2.2 Scatter plot for vote shares (2020) and satisfaction composite indicator (2018).

Source: MA62 Stadt Wien, Viennese Life Quality Survey 2018, Author's own elaboration. 
the probability of voting for Greens and Neos. Overall, these findings indicate that the increasing influence of social-spatial disparities in income inequality suggested by the correlation analysis (such as lower levels of satisfaction with one's housing situation, neighbourhood and financial situation), relate to specific electoral outcomes at the district level.

Two complementary explanations might justify the correlation results. First, the findings appear to suggest that the Red Vienna myth has (at least partly) lost its ideological grip in some Viennese districts: while electoral performance confirms the SPÖ as the undisputed ruler of the City, its traditional redistributive social policy repertoire may not be sufficient to achieve a significant number of votes in those areas with a higher concentration of more affluent residents than in those areas with less affluent residents. Second, the correlation results hint that those areas where, on average, Viennese residents are less satisfied with their general living conditions have higher SPÖ vote shares. A cautious interpretation may convey the impression that the SPÖ is still conceptualised by its voters as a service provider, in line with its traditional mission. However, further research would be needed to cast further light on the link between service supply and voting patterns at an individual level.

\section{Conclusions}

This chapter mapped the persistence of the SPÖ in Vienna in the national and municipal elections over the last 30 years. Seeking to go beyond explanations hinging on party system organisation, we linked the analysis of the SPÖ's electoral success in Vienna to the redistributive municipal welfare system built over a century. Therefore, we framed our investigation by employing the concept of redistribution, which helped us to understand how redistributive policies still constitute a terrain where parties compete for votes.

The data points out how the red island trope still describes the political identity of the Austrian capital. While the political preferences of most Austrian federal states' capitals swung since the late 1990s, the SPÖ was able to retain its control of Vienna. This contrasts with other European capital cities, such as Stockholm or London, which have undergone political change in the last decades. As the findings show, the diverging spatial patterns of voting outcomes between the national and municipal elections support the argument that Vienna has been successful in keeping its reputation as a just, social-democratic city thanks to its local redistributive policies. While the SPÖ received the 
majority of the votes for the National Council elections in almost all Viennese districts until the 2002 election, this spatial dominance was progressively weakened, as the ÖVP and the Greens increased their share of votes in more and more districts over the years. However, regarding the municipal elections, the SPÖ has been able to retain its power, with very few districts voting for the ÖVP and the FPÖ. This marked contrast to the outcomes at the national level seems to suggest residents' endorsement of the social-democrats' local redistributive policies.

Nevertheless, our correlation analysis of municipal elections at the district level revealed that socio-economic and spatial divides are eroding the SPÖ's electoral base, possibly fuelling protest votes, as indicated by higher FPÖ shares and lower turnout rates in areas with low satisfaction. These findings resonate with results from opinion polls of the 2020 municipal elections, where a majority of FPÖ voters indicated that they perceived of Vienna as being run-down and of losing its quality of life (Sora, 2020). As FPÖ voters in the 2020 municipal elections tended to be young, blue-collar workers (Sora, 2020), Vienna's redistributive policies may not have been fully able to cater for some of its least-well off population. Thus, the FPÖ capitalises on such discontent, attracting the SPÖ's traditional working-class electoral base, which is especially evident in the southern and northeastern outskirts of Vienna. On the contrary, according to Sora's opinion poll (2020), SPÖ voters appear to see Vienna as a city worth living in. Our analysis suggests that this is related to areas that, on average, show lower satisfaction with the quality of the neighbourhoods, housing and financial situation, since these areas negatively correlate with the share of SPÖ's votes. This finding conveys the impression that, at the local level, the SPÖ is mainly conceived of as a front-line service provider, possibly implying a positive public perception with regard to its ability to design effective policies to address problematic living conditions.

In general, the evidence showed that districts with higher levels of life satisfaction negatively correlate with the SPÖ and FPÖ vote shares at municipal elections. Our analysis appears to hint that the SPÖ may fall short of capturing the requests from the better-off sectors of the local population, which have partly turned to the ÖVP, Greens and Neos. This finding may indicate incipient (yet not decisive) signs of new political cleavages, rendered in the literature by Inglehart's materialism/postmaterialism dichotomy, Kriesi and colleagues' 'winners and losers of globalisation' argument and Hooghe and Marks' 'GreenAlternative-Liberal and Traditional-Authoritarian-Nationalist' divide 
(Ford and Jennings, 2020, p. 298). These authors submit how emerging political cleavages see contemporary Western society as being split along the lines of highly educated, highly skilled and mobile class individuals and less qualified, less mobile and more traditional individuals (ibid.).

Ultimately, this chapter showed that the scope and generosity of local redistributive policies may act as a pull attracting voters. This indicates that Vienna's social-democratic control and its reputation as a just city may depend upon the SPÖ's ability to address contemporary socio-economic and ecological challenges, while preserving its deepseated redistributive policy approach.

\section{Notes}

1 The choice of this year as the first temporal point is due to the fact that 1995 is the first year with available data from the life satisfaction survey and 1996 is the closest electoral year.

2 https://bit.ly/3tOUAtK

\section{References}

Abedi, A. and Siaroff, A., 1999. The mirror has broken: Increasing divergence between national and Land elections in Austria. German Politics, 8(1), pp. 207-227.

Art, D., 2007. Reacting to the radical right: Lessons from Germany and Austria. Party Politics, 13(3), pp. 331-349.

Ennser-Jedenastik, L. and Bodlos, A., 2019. Liberal parties in Austria. In: Van Haute, E. and Close, C., eds., 2019. Liberal parties in Europe. London and New York: Routledge, pp. 129-145.

Ennser-Jedenastik, L., and Hansen, M.E., 2013. The contingent nature of local party system nationalisation: The case of Austria 1985-2009. Local Government Studies, 39(6), pp. 777-791.

Fainstein, S.S., 2011. The just city. Ithaca, NY: Cornell University Press.

Ford, R. and Jennings, W., 2020. The changing cleavage politics of Western Europe. Annual Review of Political Science, 23(1), pp. 295-314.

Fraser, N., Honneth, A., Golb, J., Imgram, J. and Wilke, C., 2003. Redistribution or recognition?: A political-philosophical Exchange. London: Verso.

Graicer, I., 1989. Red Vienna and municipal socialism in Tel Aviv 1925-1928. Journal of Historical Geography, 15(4), pp. 385-401.

Hagerty, M.R., Naik, P. and Tsai, C.-L., 2000. The effects of quality of life on national elections: A multi-country analysis. Social Indicators Research, 49(3), pp. 347-362.

Hatz, G., Kohlbacher, J. and Reeger, U., 2015. Socio-economic segregation in Vienna: A social-oriented approach to urban planning and housing. In: 


\section{Elisabetta Mocca and Michael Friesenecker}

Tammaru, T., Van Ham, M., Marcińczak, S. and Musterd, S., eds., 2015. Socio-economic segregation in European capital cities. East meets west. London and New York: Routledge, pp. 80-109.

Kadi, J., 2015. Recommodifying housing in formerly "Red" Vienna? Housing, Theory, and Society, 32(3), pp. 247-65.

Kadi, J. and Suitner, J., 2019. Red Vienna, 1919-1934. In: Orum, A.M., ed., 2019. The Wiley Blackwell encyclopedia of urban and regional studies. Wiley Blackwell, pp. 1-5.

Kramer, G.H., 1983. The ecological fallacy revisited: Aggregate-versus individual-level findings on economics and elections, and sociotropic voting. The American Political Science Review, 77(1), pp. 92-111.

Lieske, J. 1990. The correlates of life quality in U.S. metropolitan areas. Publius, 20(1), pp. 43-54.

Novy, A., and Hammer, E., 2007. Radical innovation in the era of liberal governance: The case of Vienna. European Urban and Regional Studies, 14(3), pp. 210-222.

Novy, A., Hammer, E. and Leubolt, B., 2009. Social innovation and governance of scale in Austria. In: MacCallum, D., Moulaert, F., Hillier, J. and Vicari Haddock, S., eds., 2009. Social innovation and territorial development. Surrey: Ashgate Publishing, pp. 131-148.

Öhlinger, W., 1993. Das Rote Wien, 1918-1934: Historisches Museum der Stadt Wien, 17.6.-5.9. 1993. Vol. 177. Eigenverlag der Museen der Stadt Wien.

Ouweneel, P. and Veenhoven, R., 2016. Happy protest voters: The case of Rotterdam 1997-2009. Social Indicators Research, 126(2), pp. 739-756.

Sora. 2020. Vienna City council elections 2020. [online] Available at: https:// bit.ly/3hx6O7C [Accessed 17 May 2021].

Stadt Wien. 2020. Statistisches Jahrbuch der Stadt Wien 2020. [pdf] Available at: https://bit.ly/3btivsc [Accessed 17 May 2021]. 